IZA DP No. 8199

Human Capital Mobility: Implications for Efficiency, Income Distribution, and Policy

David E. Wildasin

May 2014 


\title{
Human Capital Mobility: Implications for Efficiency, Income Distribution, and Policy
}

\author{
David E. Wildasin \\ University of Kentucky \\ and IZA
}

Discussion Paper No. 8199

May 2014

IZA

P.O. Box 7240

53072 Bonn

Germany

Phone: +49-228-3894-0

Fax: +49-228-3894-180

E-mail: iza@iza.org

\begin{abstract}
Any opinions expressed here are those of the author(s) and not those of IZA. Research published in this series may include views on policy, but the institute itself takes no institutional policy positions. The IZA research network is committed to the IZA Guiding Principles of Research Integrity.

The Institute for the Study of Labor (IZA) in Bonn is a local and virtual international research center and a place of communication between science, politics and business. IZA is an independent nonprofit organization supported by Deutsche Post Foundation. The center is associated with the University of Bonn and offers a stimulating research environment through its international network, workshops and conferences, data service, project support, research visits and doctoral program. IZA engages in (i) original and internationally competitive research in all fields of labor economics, (ii) development of
\end{abstract} policy concepts, and (iii) dissemination of research results and concepts to the interested public.

IZA Discussion Papers often represent preliminary work and are circulated to encourage discussion. Citation of such a paper should account for its provisional character. A revised version may be available directly from the author. 


\section{ABSTRACT}

\section{Human Capital Mobility: Implications for Efficiency, Income Distribution, and Policy*}

Mobility of highly-skilled workers affects and is affected by labor market conditions, taxes, and other policies. This paper documents the demographic and fiscal importance of international migration, especially in aging societies, reviews the efficiency and distributional effects of mobility, and analyzes the economic incidence of fiscal transfers to low-skilled workers that are financed by taxes on imperfectly-mobile high-skilled workers in a dynamic model, distinguishing the short-run, transitional, and long-run gains and losses to contributors and beneficiaries.

JEL Classification: J11, J24, J61, H2, H5

Keywords: migration, taxes, redistribution, dynamic incidence

Corresponding author:

David E. Wildasin

Martin School of Public Policy

University of Kentucky

Lexington, KY 40506-0027

USA

E-mail: dew@davidwildasin.us

\footnotetext{
* An earlier version was presented at the CESifo conference on "Cross border mobility of students and researchers: financing and implication for economic efficiency and growth", Venice, Italy, July 16-17, 2012. I am grateful to conference participants and to the editors for helpful comments.
} 


\section{Introduction}

Human capital formation and utilization - stated more concretely, though less comprehensively, education and work - are affected, in a multitude of ways, by economic conditions and by economic policies. Labor market conditions - most notably, the "education premium" of higher earnings (and lower risk of unemployment) enjoyed by those with more education - directly affect the incentives for investment in human capital. Direct and indirect public expenditures and tax policies in support of educational institutions, individual students and their families, and workplace-related training and skill developments exemplify the types of policies that can affect the demand for and cost of investment in human capital. Through their effects on labor supply, including intensity of work effort, choice of occupation, and age of retirement, tax and expenditure policies also affect labor supply over the life cycle, and thus the utilization of human capital.

Because people carry their human capital with them, investment in and utilization of human capital involves an important locational dimension. The fact that people are mobile, to a greater or lesser degree, means that they may not be employed in the place where they go to school, receive job training, or otherwise undertake human capital investment. Indeed, over the course of a lifetime, a person may reside and work in many different locations - sometimes in different cities within relatively small region, sometimes within different subnational regions such as states or provinces, and sometimes within different countries. Because human capital is typically acquired relatively early in the life cycle, the rewards that motivate human capital investment may thus ultimately materialize well after the investment is made, in many different locations.

Needless to say, it is generally impossible for people to know with certainty where they will live and work during their lifetimes, as locational choices are subject to innumerable contingencies. As is documented in greater detail below, and as is well known, migration rates do tend to vary systematically among population subgroups. In the present context, it is especially important to note that better-educated people tend, on average, to exhibit high degrees of lifetime mobility, no doubt partly because the private returns to such mobility are high. In addition, some public policies foster the mobility of those who invest in and obtain high levels of human capital. To provide just one illustration, governments often support programs that facilitate and even promote the international exchange of scholars and researchers as students or at early stages in their careers. Such programs do not merely provide immediate (but temporary) access to opportunities for study and research. they also contribute to generalized "mobility capital", via language skills, acculturation, and increased familiarity with institutions and practices in other nations, as well as to the growth of professional networks, that may later result in employment opportunities with former fellow students, researchers, or others. 
The mobility of human capital raises a host of issues that deserve careful analysis. Market-driven mobility of workers may enhance efficiency, by directing labor away from less-productive and toward more-productive employment. It also, however, raises the prospect of a "brain drain", which may undermine the case for public-sector support for education spending, on the grounds that the benefits from such spending "escape" from the jurisdiction (locality, state/province, nation) that pays for it. The movement of highly-educated workers may also affect overall economic performance, both in origin and in destination regions, as well as the productivity and incomes of less-skilled workers and of other productive resources such as capital and natural resources. Public policies that expand opportunities for young scholars, researchers, and other prospective "knowledge workers" can accentuate these and other migration-related economic effects.

This paper seeks to highlight some of the economic implications of the mobility of highlyskilled workers for economic efficiency and for income distribution, and to examine, admittedly quite selectively, some of the policy issues associated with human capital mobility. To provide a background and motivation for the subsequent discussion, it begins, in the next section, with a brief overview of migration experience. Section 3 discusses some of the efficiency and distributional implications of human capital mobility. When market signals are undistorted, migration allows resources, including skilled labor, to flow from less-productive to more-productive uses, a potentially important efficiency benefit from human capital mobility. The movement of productive resources, including skilled labor, also affects relative factor scarcities in different locations, which in turn affects factor prices and the distribution of income. Fiscal systems - both tax and expenditure policies - may distort market-driven resource flows, however, even as these flows may interfere with, or contribute to, the attainment of distributional or other objectives of fiscal policies. Section 3 also emphasizes the fact that the decision to invest in human capital is a decision made under conditions of uncertainty, including uncertainty about future market returns to education and training. Human capital mobility, or the lack thereof, affects the scope of lifetime market opportunities and thus the riskiness of investment in human capital.

Many policy decisions and underlying economic factors influence the potential mobility of human capital. The fundamental economic costs of migration include not only transportation of people and their possessions but also the costs of acquiring information about market opportunities and of psychic adjustment to new neighborhoods, regions, cultures, and languages. At different times and places, these costs hinder the potential movement of people to greater or lesser degrees. In addition, public policies can raise or lower the costs of migration directly or indirectly. Immigration policies, including not only visa and quota restrictions but the magnitude of effective penalties for illegal migration, are one obvious - and much debated - set of policy instruments that affect mobility. Labor market regulations, such as occupational licensure and degree recognition policies, also influence the payoff to migration, as do regulations regarding access to public (and 
sometimes private) goods and services for native and migrant individuals. For analytical purposes, the imperfect mobility of skilled labor and other factors of production raises challenging issues for economic modeling and policy analysis. In particular, in the literature of public economics, much research has exploited simplified polar-case assumptions, such as the assumption that one resource - say, capital - is perfectly mobile, while other resources - labor, for instance - are perfectly immobile. Analyzes based on such polar cases can be highly illuminating, but they leave open the question of empirical applicability: how can one say whether one resource or another is or is not "mobile", "immobile", or somewhere in between?

Section 4 sketches an explicitly dynamic framework within which factor mobility is modeled as a stock-adjustment mechanism and the "degree of factor mobility" is characterized in terms of the speed with which factor stocks adjust to perturbations. This framework is then used to investigate the impacts of changes in the tax treatment of imperfectly mobile highly-skilled (and high-income) households or on capital that are used to finance redistributive transfers to lower-income households. The economic impacts of such policies vary over time, with benefits and costs in the short run that can be offset or even dominated by long-run effects that emerge gradually as the dynamic response to policy changes unfolds. This analysis, though highly stylized, can be used to show that the distributional and welfare effects of redistributive policies may be quite sensitive to the degree of factor mobility. Section 4 discusses some of the implications of dynamic factor adjustment for political economy and policy analysis. Section 5 provides a brief summary and conclusion.

\section{Demographic Background}

Migration appears to be a persistent feature of well-integrated market-oriented economic systems, such as that of the US. For instance, a substantial portion of the US population - in recent years, some $12 \%$ of the total - relocates every year. Some of this migration occurs on comparatively small geographical scales, much of it the result of changes in desired residential housing due to changes in family status (marriage, birth of children) or other factors that do not result in significant changes in employment status. But it is equally true that people in the US regularly migrate over larger geographical scales, such as US states. More than $1.5 \%$ of the US population moved from one state to another during the period 2005-2009, and this is historical low: the rate has ranged from 2-3\% since the 1940s (Ihrke et al. 2011). This ongoing migration has produced a population distribution in which less than $60 \%$ of the total population, and only $50 \%$ of those older than 25, resided in their state of birth in 2010. It has also resulted in significant net population shifts among states and regions over time; for instance, whereas some $70 \%$

of the residents of the Midwest (one of four large US Census regions) were born in that 
region, only $56 \%$ of those residing in the South and only $49 \%$ of those residing in the West, were born in these regions (Ren, 2011). However, while the cumulative effects of net migration have been important, it is important to note that gross interstate and inter-regional migration flows have consistently and substantially exceeded net migration flows, often by an order of magnitude. A large fraction of internal migration in the US takes the form of "cross hauling" of population, with the net flow of people from one location to another typically a result of substantially offsetting gross flows between them.

In other countries, internal migration may be somewhat less prevalent than in the US, a country long noted for its flexible labor, housing, and other markets, but the US experience, though it may differ in degree from that of other nations, is certainly not entirely unique. Canada, for example, also exhibits a high degree of interprovincial migration. In the past decades, economic liberalization in China has been accompanied by de facto relaxation of internal migration controls, resulting in the rural/urban and interprovincial movement of many tens of millions of people.

At the international level, migration has waxed and waned. Long run trends - events such as the opening up of the Western Hemisphere after the age of exploration, technological change such as the replacement of sail by steam power in ocean shipping, the building of railroad systems in North America, and the improvement of global communications have worked to reduce the real economic costs of migration. Periods such as the 19th century witnessed large-scale movements of people and capital to the western hemisphere, with major effects on regional and global economic development and income distribution. ${ }^{1}$ Population movements are sometimes triggered by wars and by the collapse of existing nations and empires, or by the creation of new ones. In the past century, policies such as the immigration restrictions imposed by the United States in the interwar period, sustained movement toward increased economic integration within the European Union starting with the Treaty of Rome itself and continuing to the present, including the Schengen Agreement, and liberalized immigration policies in the US since World War II, including relatively lax border controls allowing significant illegal immigration, have all had significant effects on international migration.

\section{Fertility, Migration, and Aging Populations}

In recent decades, international migration has emerged as a critical determinant of aggregate demographic change, especially in high-income countries. This is due, in part, to the remarkable and perhaps historically unprecedented collapse in fertility in these countries. The "fertility bust" of the rich countries is illustrated graphically in Figure 1 provides some data for individual predominantly high-income countries, showing that fertility rates that now lie well below the "replacement rate" of 2 children per woman. ${ }^{2}$

\footnotetext{
${ }^{1}$ See, e.g., Hatton and Williamson (1998) and O'Rourke and Williamson (1999).

${ }^{2}$ The graph is designed to illustrate the common trend of falling fertility among these countries. South Korea warrants
} 
Note from Figure 2, however, fertility rates, though falling in all major regions of the world, still differ significantly by level of economic development. The world fertility rate, presently at about 2.3 , closely tracks the fertility rates of middle income and non-OECD high-income countries, while fertility rates in low income countries are still above 4.

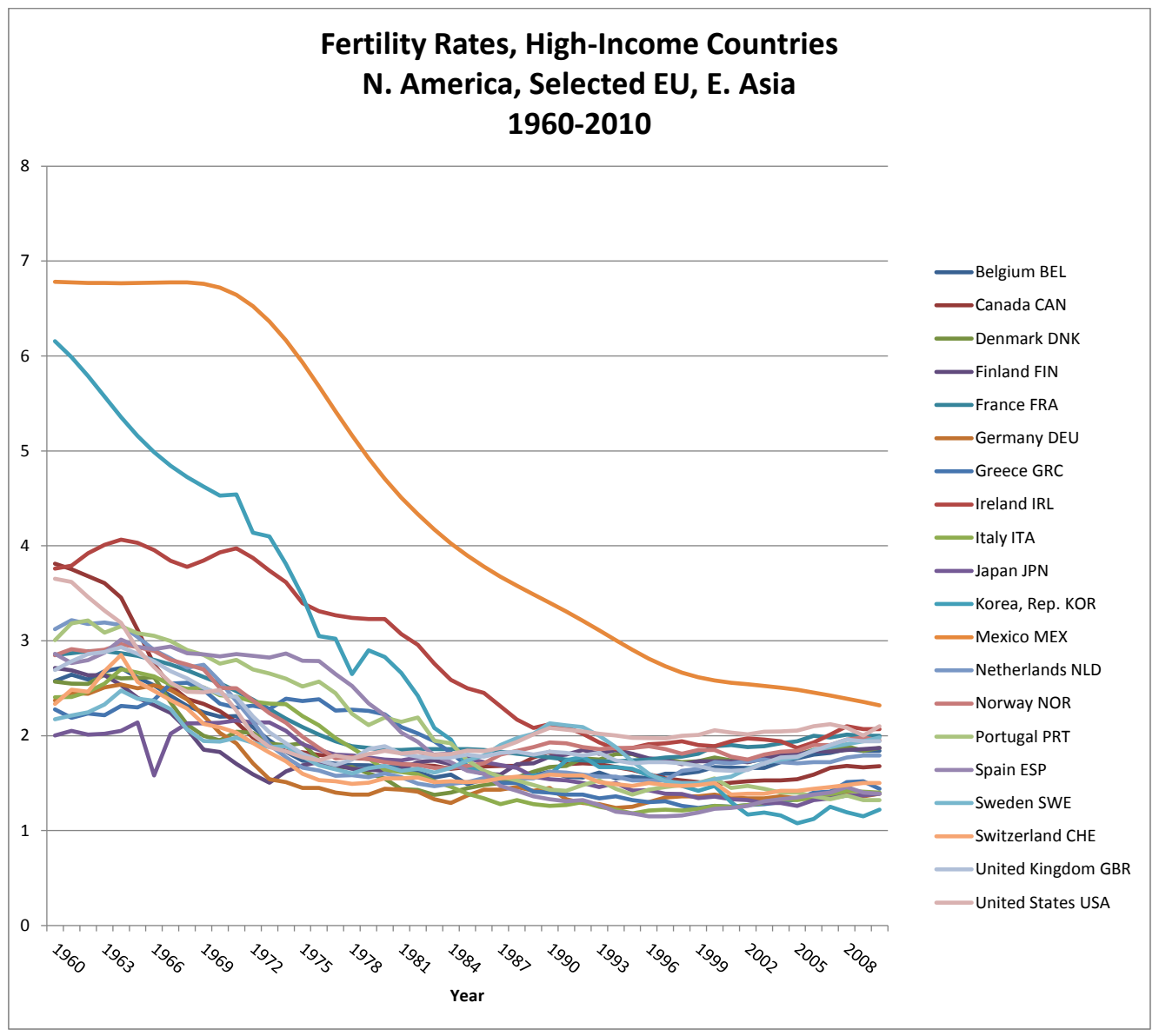

Figure 1

special note, as its fertility rate was greater than 3 until the mid-1970s has fallen dramatically to a mere 1.3, the lowest of the OECD countries. Mexico, the poorest of the North American countries, continues to have above-replacement rate fertility, but its fertility rate has fallen by well more than half, from nearly 7 , in the 1960 s. 


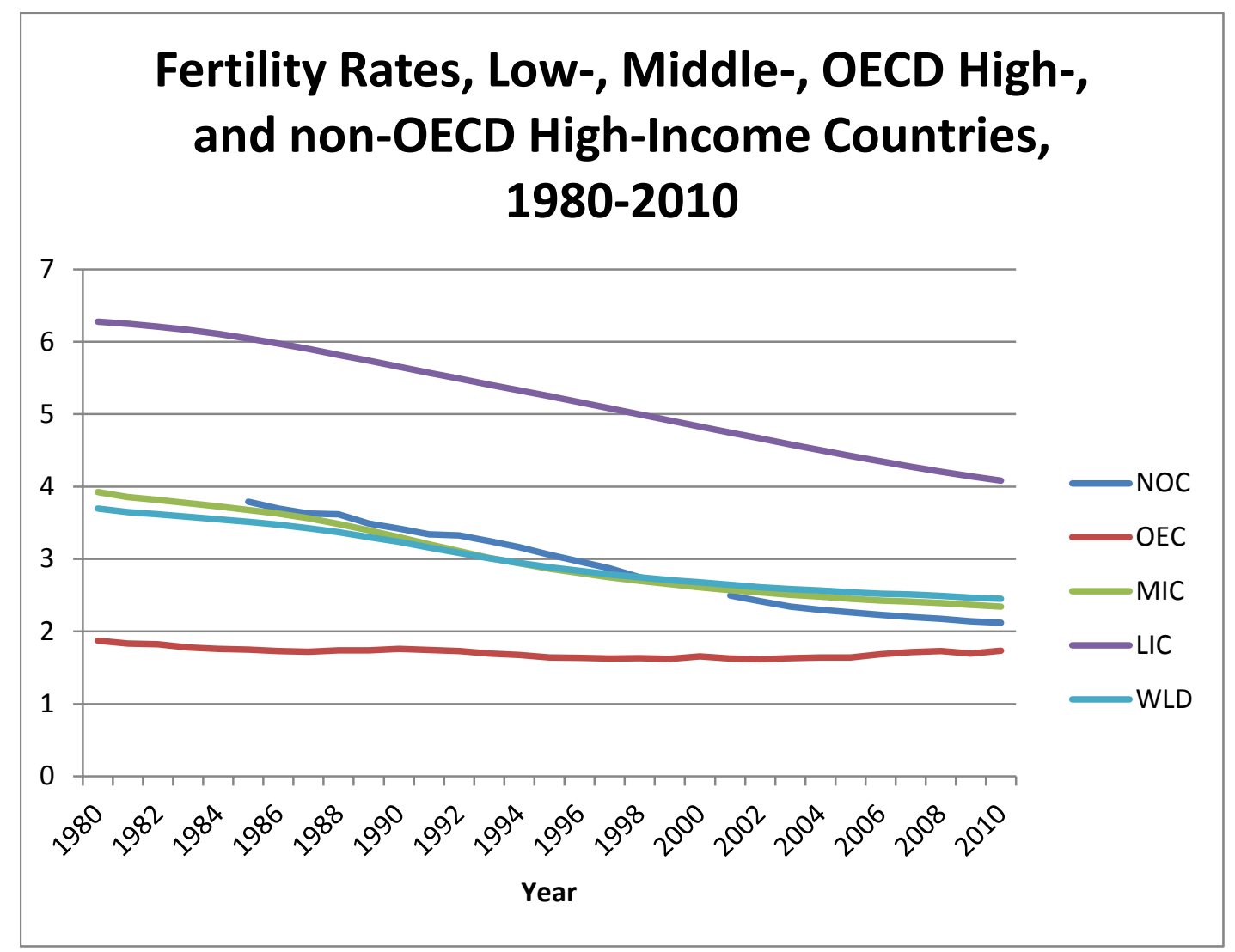

Figure 2

Falling fertility rates in high-income countries have been accompanied by rising rates of immigration from less-developed and transition countries to more affluent countries. Figure 3 illustrates the trend over the past decade in 16 eurozone countries, where one can see that net migration is far larger than the rate of natural increase in these countries, a trend that was already evident in the EU-15 countries as of the mid-1980s. Migration rates have of course differed by country; in Germany, for example, net migration exceeded the rate of natural increase in almost every year from 1975 onward, whereas countries like Spain only began to experience net immigration flows by the mid-1990s. The impacts of these high net migration flows, combined with low fertility rates, naturally have 
combined to change the demographic composition of the EU countries. At present, the foreign-born make up some 48.9 million people, or $9.7 \%$ of the total EU-27 population, with the proportion ranging between $11-16 \%$ for a number of large countries, including Belgium, France, Germany, Greece, Ireland, the Netherlands, Spain, Sweden, and the United Kingdom; among larger countries, Austria leads the way with a foreign-born population of $15.5 \%$ (Vasileva, 2012).

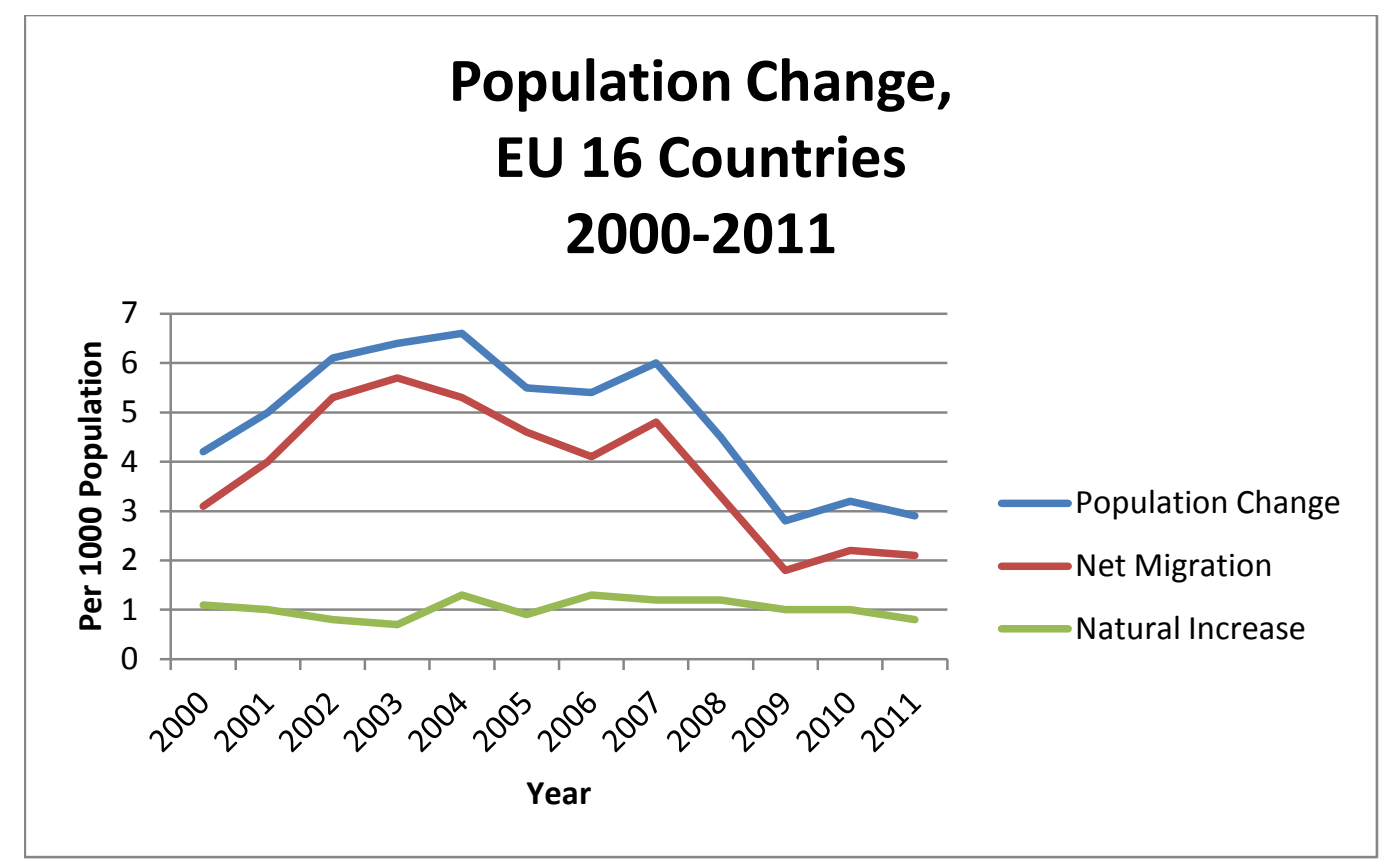

Figure 3

The foreign-born share of the population in affluent countries like the US and those of the EU, as large as it may be today, is certain to rise for many years into the future. This would true even if immigration were suddenly to stop abruptly, by virtue of the differing age structures of the native- and foreign-born populations. Immigrants in these countries are disproportionately in the working-age part of the life cycle, as shown in Figure 4 for the case of the EU countries. This means that the native-born population 
share will shrink over time as the native born age out of the population at a faster rate than the foreign-born.
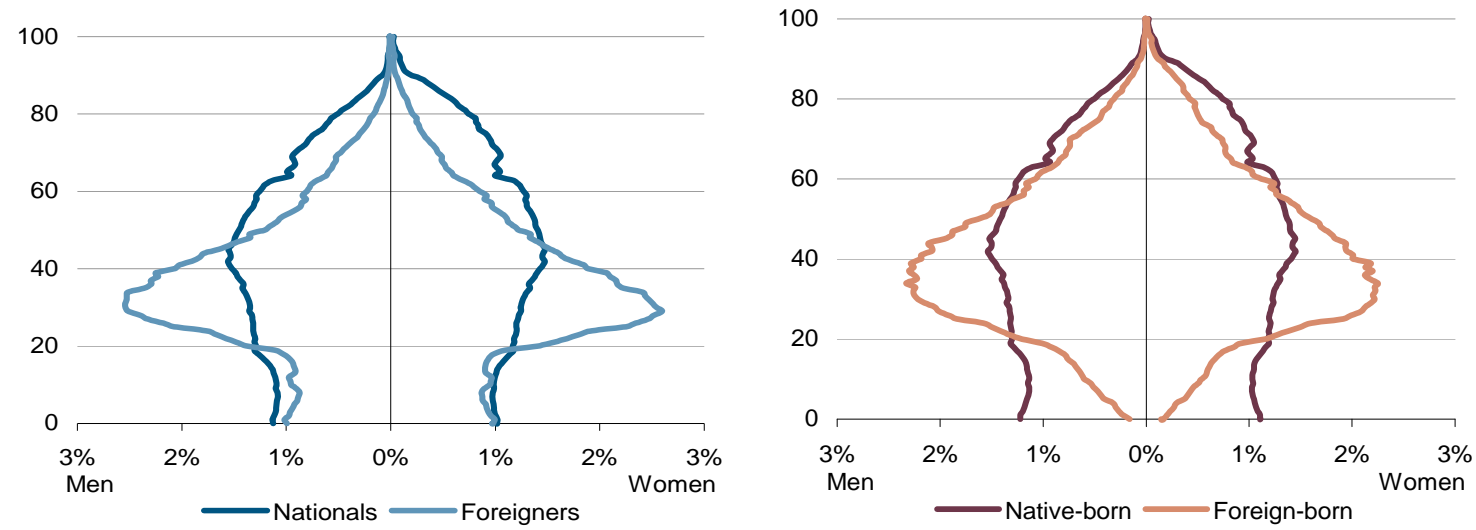

Figure 4

Fertility busts increase the proportion of the population in older age groups, while fertility booms do the opposite. The populations of the rich countries of the world have been aging steadily for many decades, a trend that is expected to continue for at least several decades. For instance, current Eurostat projections for a selection of EU countries, shown in Figure 5, call for the old-age dependency ratio to rise from its current level of slightly more than $25 \%$ to an unprecedented $50 \%$ by 2050 and still somewhat higher in the years that follow. Such projections are necessarily somewhat speculative, but demographic trends exhibit considerable inertia, as already displayed in the fertility rate data of Figure 1. For the world as a whole, everyone who will reach the age of 65 by, say, 2050, is already over 15 years of age. Barring major wars, epidemics, or other catastrophes, and barring substantial increases in net immigration, projections like those in Figure 5 are quite likely to be realized. 


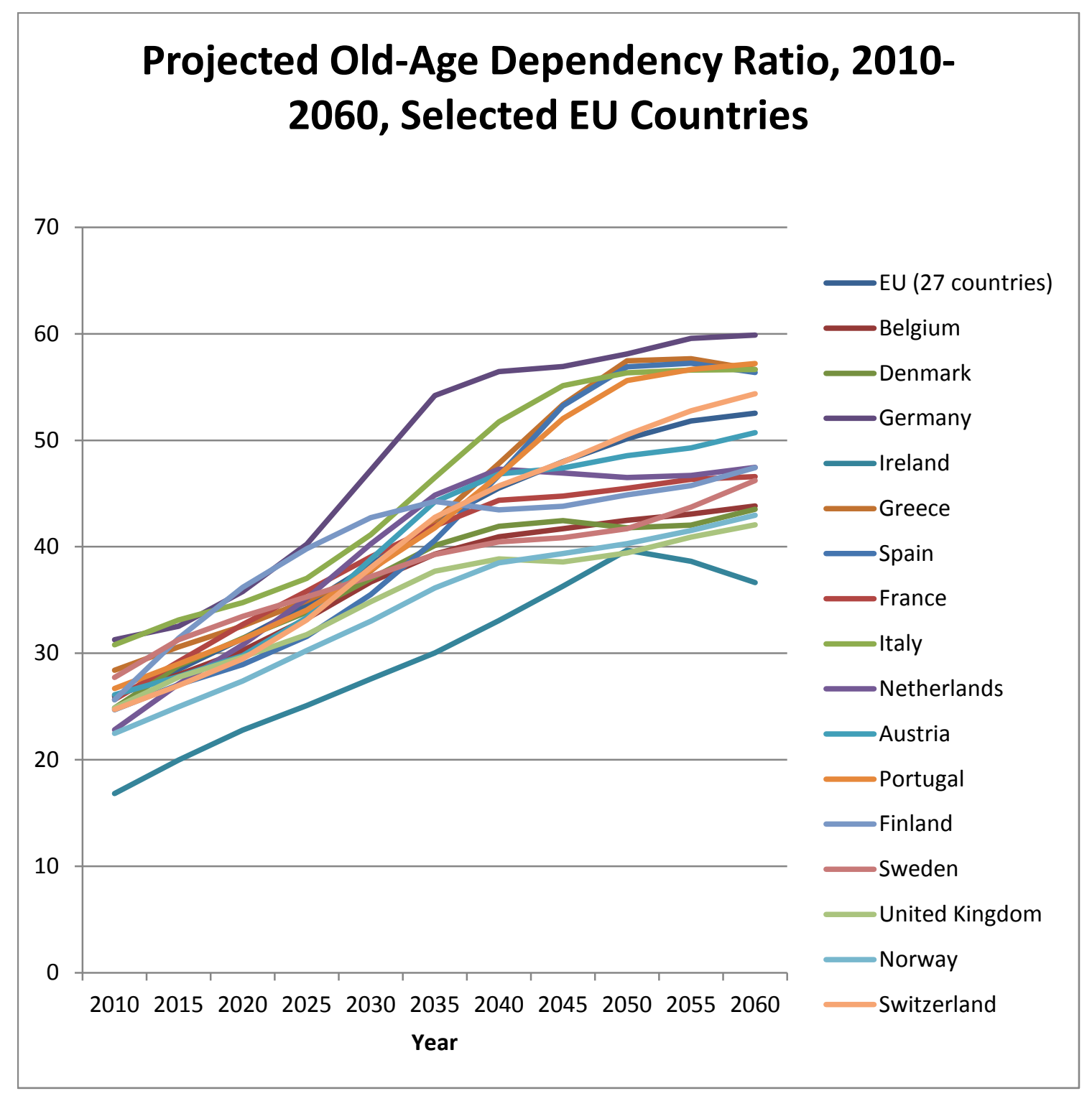

Figure 5 


\section{Migration and Fiscal Systems}

Dramatic aging of the population has far-reaching economic implications. For fiscal systems like those of the OECD countries, population aging is sure to be the source of considerable stress. By standard metrics, public expenditures in the OECD countries are at historically high levels, and these countries devote very large shares of public expenditures to age-sensitive programs such as public pension and health care systems whose costs rise as populations age. To the extent that their expenditures are taxfinanced, these countries derive most of their revenues - via payroll, personal income, and consumption taxes - from the working-age portion of the population. For at least the past two decades, the challenges facing countries with age-imbalanced population distributions and heavily age-conditioned fiscal systems have attracted the interest and attention of scholars and these challenges are sure to become increasingly prominent in popular and policy debates in the future. ${ }^{3}$

It is well-recognized that the fiscal impacts of migration depend importantly on their attributes. As is often discussed in popular and policy debates, immigrants with poor skills, low education levels, and ill health, are, by contrast, less likely to find jobs and to achieve high earnings, and are accordingly less likely to make substantial fiscal contributions than native-born workers. Such immigrants are also more likely to draw benefits from social welfare programs. Given the powerful incentives for immigrants from poor countries to migrate to richer nations, it is perhaps not surprising that many empirical studies have found that immigrants, particularly those from poor countries, depend disproportionately one income support and similar social welfare programs. $\left({ }^{4}\right.$ Of course, immigrants may well assimilate gradually into the labor markets of destination countries, and thus their fiscal impacts over time may change significantly. For both highly-skilled and high-income immigrants and for those at the lower end of the skill and earnings distribution, it is perhaps of greatest interest to assess their fiscal impacts in present value terms, taking into account the fact that the fiscal contributions that they make, or the fiscal burdens that they impose, may change substantially over the life cycle (Wildasin $(1999,2009)$.

Most economies - especially in countries with extensive systems of social insurance and redistribution, such as the US, Canada, and many EU countries - exhibit significant income inequality and rely on revenue systems in which higher-income households pay for a large fraction of government expenditures. This is true within countries as well, although generally to a lesser degree, as the redistributive functions of subnational governments

\footnotetext{
${ }^{3}$ Among many studies that examine the fiscal implications of population aging, see, e.g., Bös and Cnossen (1992) for one relatively early set of contributions. More recent work includes Wildasin (1999), Gustman and Steinmeier (2000), Storesletten (2000), Dang et al. (2001), [additional references].

${ }^{4}$ Among those who have investigated immigrant participation in social welfare systems, see e.g., Hanson and Lofstrom (2003, 2009), Wadensjö and Orrje (2002), Riphahn (2004), Collado and Iturbe-Ormaetxe (2004), and Bollinger and Hagstrom (2008).
} 
are less extensive than those of national governments. In such economies, the migration of highly-skilled individuals, who are typically highly-skilled, well-educated, and healthy, may immediately assimilate effectively into destination-region labor markets, achieving high earnings, paying substantial amounts of consumption-based taxes, and participating, as significant contributors, in public pension and other social insurance and social welfare systems. For this reason, the economic and fiscal impact of migration of the highly-skilled is disproportionately greater than the head-count numbers involved: the highly-skilled may be (literally) "worth their weight in gold" to the fiscal systems of the regions where they reside.

Recent research confirms the quantitative importance of migration of highly-skilled workers from developing to developed countries. As documented in Docquier and Rapoport (forthcoming), very large fractions of better-educated young people in developing nations have migrated to developed countries, noting in the conclusion of their survey that "highskill migration is becoming the dominant pattern of international migration" in recent decades. The "brain drain" dilemma, long ago noted by Bhagwati (1976a, b), appears, if anything, to be increasing in importance. Migration research has long since established that highly-skilled workers in the US and other developed economies are highly mobile; for instance, Ehrenberg and Smith (1988, p. 360) explain that age is the most important determinant of migration, with young people moving more than old, and that "education is the single best indicator of who will move within an age group. ... [C]ollege education ... raises the probability of migrating the most"; emphasis in original. ${ }^{5}$ In view of the high degree of mobility of highly-skilled workers within developed countries, perhaps the rising mobility of such workers on a global scale is not surprising as economic development progresses.

The persistence of high rates of internal migration by the highly skilled, for instance among US states, raises important questions for fiscal policy. State governments have played a prominent role in financing higher education spending, raising a perennial concern about whether a state's taxpayers, residents, businesses, or others benefit, on net, by supporting, via tax payments, the acquisition of human capital by young people who may then relocate to other states. As already observed, a state, or a nation, can reap significant fiscal benefits from an inflow of highly-skilled workers and, conversely, may suffer substantially from an outflow of such workers.

On the other hand, migration affects the attractiveness of human capital investment, not merely in poor regions for which improved skills may offer a passport to better economic opportunities in other regions, but also when the return to investment in human capital is subject to risk. ${ }^{6}$ It is difficult for young people in any one small region to

\footnotetext{
${ }^{5}$ For further analysis of US internal migration, see e.g. Partridge et al. (2012); for empirical analysis emphasizing migration of the well-educated see, e.g., Kodrycki (2001), Kennan (2011) and references therein.

${ }^{6}$ On incentives for human capital investment and migration, see, e.g., Vidal (1998), de la Croix and Monfort (2000), Wildasin (2000), Docquier et al. (2008), and, for a recent survey of international migration and human capital mobility,
} 
foresee what returns they may earn after acquiring better skills, and this is particularly true if skill acquisition also entails occupational specialization. For patent attorneys, nuclear physicists, organic chemists, transplant surgeons, petrochemical engineers, or labor economists, interstate or international mobility enhances the opportunity to relocate to places where demands for their specialized skills are relatively high and for a pooling of risks associated with uncertain and imperfectly correlated demands for their skills in very localized markets. Since it can be difficult to insure against future earnings risks, mobility for the highly-skilled can make investment in human capital more attractive in a dynamic economy with ever-changing market conditions. The mobility of highly-skilled labor, then, can affect both the financing of human capital investment, as regions compete for fiscally-attractive high-skill, high-income workers, as well as private incentives to invest in human capital.

It is not obvious a priori whether mobility, on balance, results in higher equilibrium levels of human capital investment, nor whether (or for whom) such investment is welfareenhancing. Empirical evidence on international migration from poor to rich countries suggests that poor countries, on balance, may be net losers from brain drains, while rich countries, the targets of net migration of the highly-skilled, benefit (see, e.g., Marchiori et al, (forthcoming). For jurisdictions that are more symmetrically situated, such as US states or EU nations, matters remain less clear, as gross migration among these jurisdictions is much higher - often by an order of magnitude - than net migration.

\section{Summing Up.}

Against the backdrop of aging populations in developed countries and the comparative youthfulness of poorer regions, migration assumes an increasingly important role as a determinant of demographic change. Increased ease of movement throughout the world - a long-term trend of falling relocation costs of all kinds - coupled with the attraction of earnings differentials provides powerful incentives for migration from poor to rich countries. The fertility bust in rich countries implies that rates of natural increase are extremely low or even negative, so much so that aggregate population change in a number of OECD countries has been dominated by migration for much of the past decade and longer. Some countries face rapidly aging populations as a result of prolonged low rates of fertility, even as they grapple with the financing of large age- and income-conditioned social expenditure programs with revenue systems that are heavily dependent on the working-age population, and particularly on high earners within that population.

Highly educated workers are particularly mobile, both within and among countries. In a world of increasing fiscal stress, due in no small part to population aging, competition for highly-skilled migrants may intensify as governments strive to maintain revenue

\footnotetext{
Docquier and Rapoport (forthcoming).
} 
bases in the face of rising expenditure commitments. What are the potential efficiency and distributional consequences of such competition? The remaining sections of this paper attempt to shed some light on this important question. To provide an analytical background for discussion, the next section briefly sketches a modeling framework that has often been used in the study of factor mobility and fiscal competition for mobile productive resources.

\section{The Efficiency and Distributional Effects of Migration: An Analytical Benchmark}

This section first presents a simplified analytical framework that is frequently used to analyze interregional factor mobility. It then shows how this framework can be used to investigate the effects of taxes, transfers, and other government fiscal policies. It concludes by recognizing some of the significant limitations of this framework, and of policy implications that may be taken from it.

\subsection{Factor Mobility without a Public Sector}

Suppose that homogeneous labor is used as one of the inputs in the production process of each of $N$ regions, $i=1, \ldots, N$, and that production of a single homogeneous numeraire good in each region is a strictly increasing and concave function $f_{i}\left(l_{i}\right)$ of the size of the regional labor force, here identified with the number of identical workers $l_{i}$. The economic system as a whole contains a labor force of size $\bar{L}$ and all workers must reside - and be employed - in some region, so that

$$
\sum_{i} l_{i}=\bar{L}
$$

Workers consume only the numeraire commodity, which is freely tradeable among regions, so that the utility or economic well-being is the same thing as earnings. Under the assumption of perfectly competitive labor markets, workers in region $i$ will be paid a wage of $w_{i}=f^{\prime}\left(l_{i}\right)$. Because of the strict concavity of the regional production functions, total earnings in region $i, w_{i} l_{i}$, are less than regional output $f_{i}\left(l_{i}\right)$. The remaining income generated in region $i, f\left(l_{i}\right)-w_{i} l_{i}$, accrues to other inputs to the production process, assumed to be perfectly fixed in amount and completely immobile. It is the presence of these fixed resources, which could include land and natural resources and possibly other inputs, that gives rise to the diminishing marginal returns to the sole variable input, labor, as represented by the strict concavity of the regional production functions. 
A simple model of this type underlies many theoretical and empirical studies of migration and, more generally, of factor mobility. Under the further simplifying assumption that labor is freely mobile among regions, the model predicts that workers are drawn to regions where wages are high and will exit low-wage regions. In this setting, migration is a spatial arbitrage mechanism, serving to reallocate labor from low-productivity to highproductivity locations. In equilibrium, all such arbitrage opportunities are fully exploited and wages must be equalized everywhere, which implies that the marginal productivity of labor is the same in all locations. Formally, the equilibrium allocation of labor, denoted by the vector $l^{*} \equiv\left(l_{1}^{*}, \ldots, l_{N}^{*}\right)$, and the equilibrium wage $w^{*}$, are obtained as the unique solution ${ }^{7}$ to the system of equations (1) and

$$
f_{i}^{\prime}\left(l_{i}^{*}\right)=w^{*}, \quad i=1, \ldots N .
$$

To gain some insight into the implications of labor mobility, the "free mobility" equilibrium described by (1y) and (2) may be compared with a hypothetical initial allocation of labor $\bar{l} \equiv\left(\bar{l}_{1}, \ldots, \bar{l}_{N}\right)$ determined, perhaps, by historical accident. Because labor is drawn to higher-wage and therefore higher-productivity locations, migration - represented in this model by the difference $l^{*}-\bar{l}$ ) between the equilibrium and initial allocations of labor - is efficiency-enhancing. Specifically, system-wide aggregate output $\sum_{i} f_{i}\left(l_{i}\right)$, and thus aggregate income, is maximized at the equilibrium allocation. This fundamental observation is illustrated in Figure 6, which shows the allocation of labor in a two-region economy. The curves labeled $M P_{1}$ and $M P_{2}$ represent the marginal productivity of labor $f_{i}^{\prime}\left(l_{i}\right)$, and their intersection determines the efficient distribution of labor between the two regions.

\footnotetext{
${ }^{7}$ Here and below, technical complications such as corner solutions (empty regions, for example) are ignored for the sake of simplicity of exposition.
} 


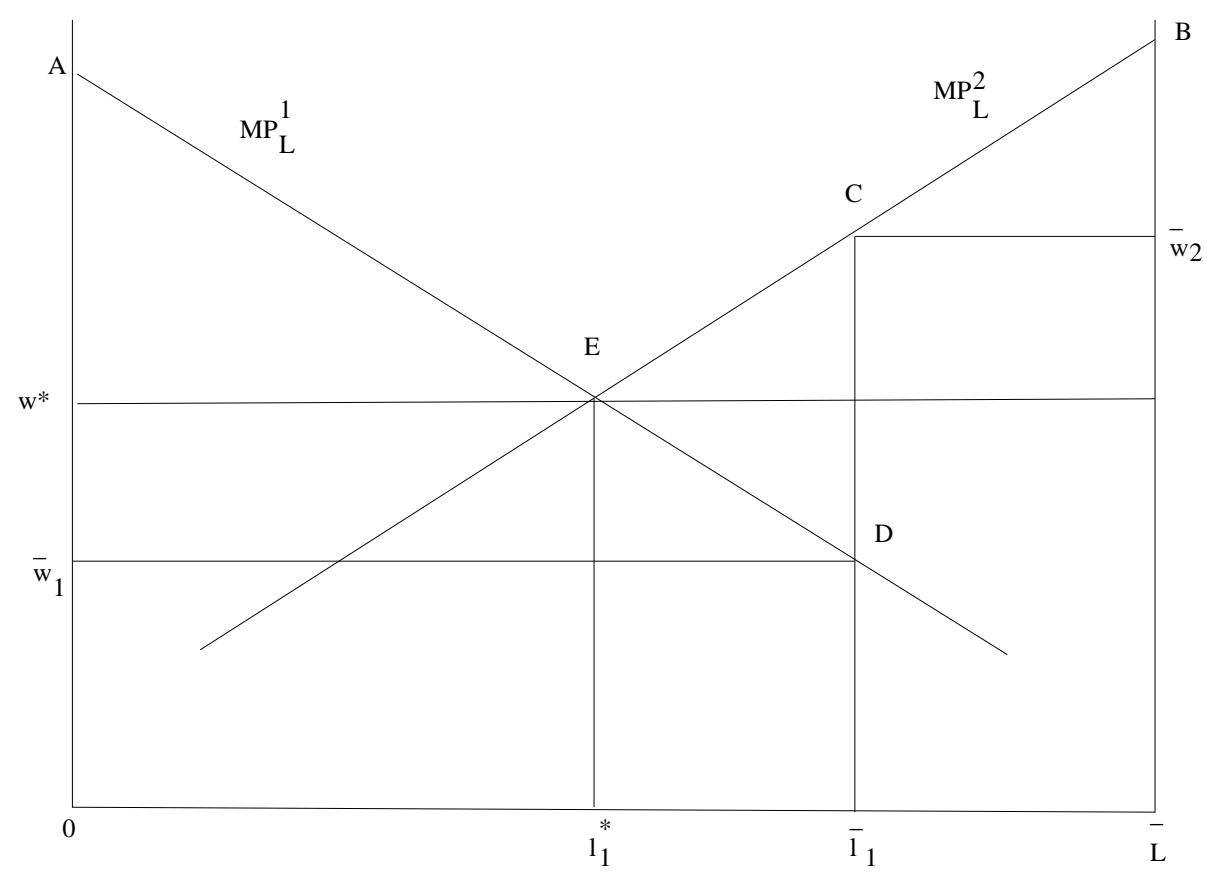

Figure 6

Figure 6 also illustrates the distribution of income before and after migration occurs. If labor is completely immobile, so that the labor markets in each region are separated, the equilibrium wage per worker in regions 1 and 2 would be given by $\bar{w}_{i} \equiv f_{i}^{\prime}\left(\bar{l}_{i}\right)$; as drawn, region 1 is the low-wage region. The incomes accruing to the owners of the other factors of production in each region are given by $f_{i}\left(\bar{l}_{i}\right)-\bar{w}_{i} \bar{l}_{i}$ and are represented in the figure by the areas $A D \bar{w}_{1}$ and $B C \bar{w}_{2}$. Comparing the situation with immobile labor to that with free migration, it is apparent that labor mobility reduces the income of the fixed resources in "origin regions", i.e., those for which $l_{i}^{*}<\bar{l}_{i}$, and increases the income accruing to the fixed resources in "destination regions", i.e., those for which $l_{i}^{*}>\bar{l}_{i}$. It also depresses earnings for workers in destination regions while raising wages in origin regions. Aggregate income of course increases by an amount equal to the increase in aggregate output, illustrated in Figure 6 by the area $B C D$.

The analysis so far shows clearly that migration affects both the efficiency of resource allocation as well as the distribution of income. Migration results in gainers and losers, with a net efficiency gain that could hypothetically be used to compensate losers, thereby producing a Pareto improvement. If the mobile resource is high-skilled labor and the immobile resources are low-skilled labor, the effect of migration is to depress the incomes of the high-skilled in regions where high-skilled workers are highly compensated, while raising the incomes of the high-skilled in regions where they are poorly compensated; in any case, migration of highly-skilled workers reduces and, in equilibrium, fully eliminates, 
any inter-regional disparities in the incomes of the highly-skilled. Whether disparities in the the incomes of low-skilled workers (or of other owners of assumedly fixed resources) are increased or decreased cannot be determined a priori.

The essential allocative and distributional implications of this analysis immediately generalize to the case where there are any number of different mobile resources; the variables $l_{i}$ need only be reinterpreted as vectors of potentially mobile resources. This modeling approach can thus be used to analyze the implications of the simulates mobility of multiple types of labor with varying skill levels, as well as the mobility of capital. Under such interpretations, the immobile resources in each region are perhaps most naturally presumed to include only natural resources such as land, minerals, and the like. Under any such generalizations, the mobility of productive resources serves as a mechanism of spatial arbitrage which reduces - and, in a free-mobility equilibrium eliminates - any inter-regional differences in returns to mobile factors. Efficiency gains - increases in aggregate output and income, and potential Pareto improvements - result from the reallocation of these factors from less-productive to more-productive locations.

Applied research on migration, past and present, attests to the empirical importance of the efficiency and distributional impacts of migration. Research by economic historians (e.g., O'Rourke et al. (1996), Hatton and Williamson (1998), O'Rourke and Williamson (1999), Lindert and Williamson (2003), and references therein) provides compelling evidence that migration and, importantly, capital mobility, as well, between Europe and the western hemisphere had substantial affects on output and income distribution during the 19th century, resulting in higher returns to mobile factors in origin countries (Europe) and lower returns to these factors in the western hemisphere (both North and South America) as labor and capital relocated from East to West to exploit factor price differentials. Returns to fixed factors in each region moved in the opposite directions. By one estimate (Lindert-Williamson, Table 5.2), migration reduced real wages in the New World by $28 \%$ during the period $1870-1910$, while raising real wages in the Old World by $7 \%$, thereby contributing to substantially reduced international dispersion of real wages - a clear indication of the effect of spatial arbitrage. Similar findings emerge from the study of internal migration within the US, where, for example, migration during the 20th century has substantially narrowed inter-regional income differentials.

More recent research has reached similar conclusions about the effects of liberalized migration policies in the modern era. Hamilton and Whalley (1984) provide a pioneering analysis of the impacts of global migration using a computable general equilibrium (CGE) model built on a framework of the type sketched here. Such models continue to be exploited, e.g., in a recent study by Walmsley et al. (2011). These authors take separate account of the migration of skilled and unskilled labor, finding relaxation of existing migration quotas, sufficient to permit an increase of $3 \%$ in international migration, would increase world income by some $\$ 300$ billion. As suggested by the discussion above, there 
would be both gainers and losers from such a policy change, both among workers and on the part of owners of nonhuman resources.

\subsection{Analysis of Fiscal Policies}

Using the basic model outlined above, it is easy to see how factor mobility can significantly affect the assessment of public policies, particularly those that directly or indirectly redistribute incomes. As already observed, migration may exacerbate or diminish earnings or income inequality within and among regions, which means that the normative desirability or political pressure for redistributive policies may increase or decrease when one or more productive resources are mobile. In addition to these possible effects on the "benefit" or "demand" side of redistributive policy, however, factor mobility also influences the "cost" side. In particular, as has been amply discussed in the now-ample literature on fiscal competition, "decentralized" redistributive policies - affect the allocation of mobile resources and raise the cost of taxes imposed upon, and of transfers granted to, mobile factors of production.

This is most easily demonstrated in the case where regions are "small" relative to external markets for mobile resources, that is, where migration or other resource flows into or out of a single region have only negligible impacts on net factor returns. Figure 7 depicts the demand for a factor of production in a region $i$ that is initially endowed with $\bar{l}_{i}$ units of labor, and in which the equilibrium (gross) wage, in the absence of labor mobility, is $\bar{w}_{i}$. Suppose that tax/transfer policies in this region are determined by a regional government that can tax or subsidize either labor or the other fixed factors in the region. In this case, given the strong simplifying assumptions that there are no labor/leisure, consumption/savings, or other behavioral margins that can affect factor supplies, any taxes or transfers, such as a tax on labor that finances subsidies to immobile resource owners, are purely lump-sum in nature. For instance, a tax on labor of the amount $t_{i}$ would simply reduce net wage incomes by that amount per unit, or by $t_{i} \bar{l}_{i}$ in aggregate, the amount of tax collected, which could then be used to finance a subsidy to immobile factor owners of that amount. By contrast, suppose that labor is freely mobile and that the net income of workers in external markets is unaffected by any policy changes, and any ensuing factor movements, in region $i$.

The situation changes completely, however, when labor is freely mobile. Now, a tax on labor cannot depress the equilibrium net income of workers; rather, the gross wage must rise sufficiently to offset the tax, leaving the net income of workers unchanged. The new equilibrium labor stock $l_{i}\left(t_{i}\right)$ is implicitly defined by the arbitrage equation

$$
f_{i}^{\prime}\left(l_{i}\right)-t_{i}=\bar{w}
$$

where $\bar{w}$ is the external net return to labor. As shown in Figure 7, which, illustratively, 
assumes that $\bar{w}_{i}=\bar{w}$, the impact of the tax on labor is to reduce the equilibrium labor force to $l_{i}\left(t_{i}\right)$. The tax on perfectly mobile labor does still produce tax revenues, equal in amount to $t_{i} l_{i}\left(t_{i}\right)$. If these revenues are transferred in lump-sum fashion to the owners of immobile resources, the net effect of the tax/transfer policy is to reduce total employment, output, and income in region $i$, to raise the gross earnings of labor, to reduce the gross earnings of immobile resources (by the amount $\left(\bar{w}_{i}+t_{i}\right) b d \bar{w}_{i}$ in the figure), and to reduce the net incomes of the owners of immobile resources (by the amount bcd in the figure).

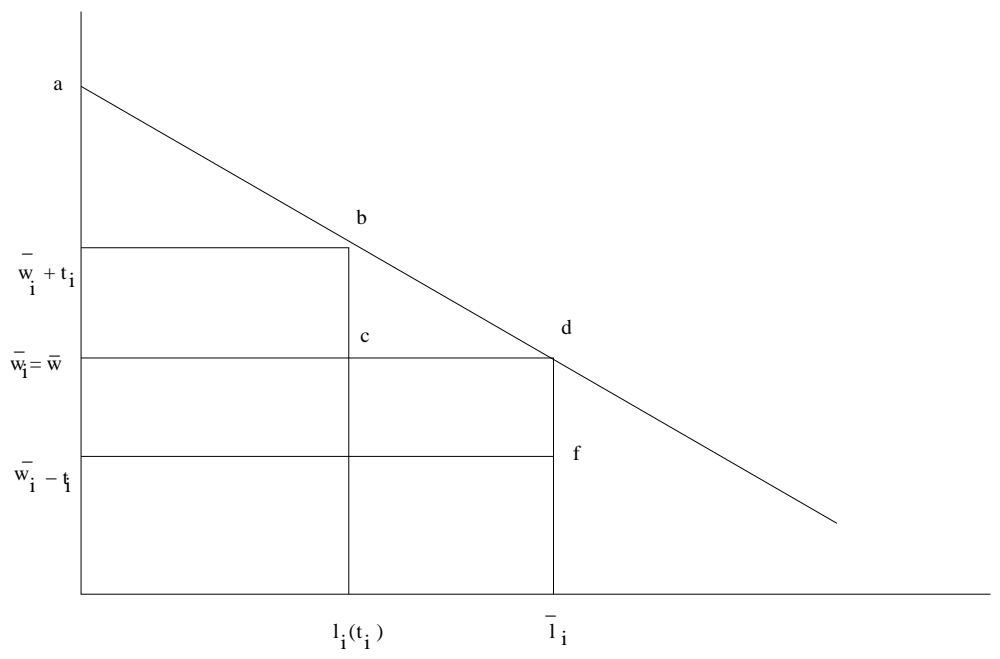

Figure 7

All of these results are standard and fairly well-known. They have potentially far-reaching implications. For instance, they appear to imply that mobility can completely reverse the fiscal incidence of redistributive policies: when labor cannot move, the owners of other fixed resources benefit from transfers financed by taxes on labor, while workers are harmed, whereas the workers completely escape the incidence of such taxes when they are freely mobile, and the recipients of transfers end up worse off, on net, as a result of these policies. Labor mobility can thus have a decisive impact on the normative desirability of such policies. Furthermore, from a political economy perspective, the alignment of political interests in support of or opposition to redistributive policies can likewise be extremely sensitive to the mobility of labor, or, for that matter, of any other productive resources.

\subsection{Some Limitations of the Analysis}

Carefully interpreted, the model presented in Section 2.2 offers important economic insights. Explicitly or implicitly, it underlies a substantial body of theoretical, empirical, 
and policy analysis on factor mobility.

On the other hand, depending as it does on standard concepts of market equilibrium, and lacking any explicit reference to time, it is probably best viewed as a model of long-run equilibrium with factor mobility. Such a concept of the long-run or stationary equilibrium distribution of population or other productive resources can be invaluable in providing a point of reference. Strictly speaking, however, a model of the long run equilibrium allocation of mobile human and nonhuman resources is not a model of factor movement as such, that is, of migration or investment flows. It is, rather, a model of the long-run determination of equilibrium factor stocks.

In a hypothetical world where mobile resources could be reallocated almost instantly, it might be appropriate to focus almost entirely on "long run" equilibria, since "short run" phenomena like factor movements would be almost unobservable. However, it is abundantly evident that spatial reallocations of labor and capital do not occur instantaneously. Equilibrating net flows of migration from low-wage to high-wage regions, even if not obstructed by policy barriers, often take place over periods of many years, and even of many decades, indicating that arrival at the "stationary" equilibrium implied by (2), in an economy with no public sector, and by (3) in an economy with fiscal policies, is, in practice, far from immediate. As a corollary, it follows that any inflows or outflow of mobile factors to favorable or unfavorable changes in policies, such as tax reductions or increases, should not be expected to take place instantly, but rather over comparably long intervals of time.

Thus, it appears that the empirical and policy relevance of "fiscal competition" for productive resources cannot properly be assessed without taking explicitly into account the intertemporal dimension of factor mobility. Furthermore, it is surely the case that the "degree of factor mobility" is not always and everywhere the same. The movement of labor and capital in a modern economy with advanced technology and communications is at least potentially far easier than was true in the 19th century or in still earlier eras. For the purposes of empirical and policy analysis, how can the "degree of factor mobility" be determined? Today, highly liquid financial assets can move around the globe with little more than a mouse click. People - especially top managers, athletes, entertainers, and others with similar incentives - can travel the globe with comparative ease, residing and working in many widely dispersed locations over the course of a single year. By any reasonable metric, such resources are "highly mobile". The circumstances facing less skilled and lower-income workers in developing countries today are not equally conducive to such mobility, although, over long intervals of time, such workers are drawn to higherwage regions within their own countries or abroad, just as in past historical experience. Without an analytical framework that can distinguish among such varying degrees of mobility, the efficiency, distributional, and policy implications of factor mobility cannot readily be discerned. 


\section{Fiscal Treatment of the Highly-Skilled in a Dynamic Context}

\subsection{A Model of Dynamic Factor Adjustment}

Motivated by the foregoing discussion, the present section outlines an explicitly dynamic model of factor mobility. In this model, which builds upon and applies an analytical presented elsewhere (Wildasin (2003a, 2011), productive and potentially mobile resources are utilized in a single small, open economy, which might be the economy of a nation, a state or province, or of a single metropolitan area or city. This model specifically postulates that there are two potentially mobile factors of production and one immobile factor of production. These resources may enter or exit the small economy, but do so subject to costs of adjustment. Specifically, as in standard dynamic models of investment, movement of resources takes place over time, that is, as flows, the effect of which is to augment or diminish, gradually, the stocks of productive resources in the local economy. As in Section 2, the assumption that the local economy is "small" means that movements of resources and of goods and services into or out of the local economy have only negligible impacts on the prices or net returns of these commodities in external markets.

The adjustment of local factor stocks is assumed to be compatible with optimizing decisions by perfectly competitive firms in the local economy, who choose levels of employment of productive resources in such a way at to maximize the present value of their profits. These decisions are affected by local tax and transfer policies, summarized, in simplified form, as net fiscal burdens, positive or negative, imposed upon the owners of each type of productive resource. When local fiscal policies change, as for instance by the imposition of higher taxes on a mobile resource, the profit-maximizing equilibrium stocks of mobile resources change, with long run effects that are essentially as outlined in the static model of Section 2. However, as noted, the adjustment of factor stocks is costly - in particular, it is assumed that adjustment costs are increasing and convex functions of the rate of inflow or outflow of resources. This means that it is not optimal to adjust factor stocks immediately in response to changes in policy. Rather, in equilibrium, the dynamic response to policy changes takes place over time. If the costs of adjustment rise at a sharply increasing rate with larger flows of resources into or out of the local economy, adjustments will take place over longer periods of time so as to take advantage of the

lower costs associated with slow adjustment, whereas adjustments will occur more rapidly if marginal adjustment costs increase only slowly. In short, productive resources in this model can be "highly mobile" or "relatively immobile", depending on the adjustment cost technologies that determine adjustment costs.

But adjustment cost technologies are not the entire story of dynamic adjustment. When multiple resources are used together in the production process, the profit-maximizing levels of each are simultaneously determined. For example, if the local production process 
involves the use of highly-skilled workers, capital, and low-skilled workers, the demand for each of these inputs will depend on the availability of the others. Although many different types of production relationships are possible, it is empirically reasonable to suppose that broad aggregates of inputs are complements in the production process, in the sense that the productivity of and (inverse) demand for any one input, like skilled labor, is increased when combined with large amounts of unskilled labor and capital. This is certainly true for standard production functions like the Cobb-Douglas or CES; in the latter case, the degree of substitutability among inputs, as measured by the elasticity of substitution $\sigma$, can vary from zero - the "Leontief" case where all inputs must be used in strictly fixed proportions, and isoquants are L-shaped - to infinity, a limiting case in which changes in factor proportions have negligible impacts on marginal products - the case of linear isoquants. In all intermediate cases, including the Cobb-Douglas, for which $\sigma=1$, an increase in any one input raises the marginal productivity of others.

To see the importance of substitution in production for the dynamic adjustment of factor stocks, consider the polar case where $\sigma=0$. In this case, factor proportions must always remain constant. This means that if one resource moves into or out of the local economy, other resources must do so as well, and at the same rate, so as to maintain rigidly fixed proportions in production, regardless of the adjustment costs for individual inputs. Indeed, if there is one fixed and immobile resource in the local economy, as is assumed in the model used here, no dynamic adjustment of factor stocks is even possible, regardless of adjustment costs. In terms of the static model outlined in Section 2, the case of fixed factor proportions corresponds to a marginal productivity $f_{i}^{\prime}\left(l_{i}\right)$ for a potentially mobile resource that falls to zero if $l_{i}$ increases at all, or that rises beyond bound if $l_{i}$ falls at all, corresponding, in Figures 6 and 7, to perfectly inelastic demand curves for the mobile resource. In this extreme case, factor proportions, and factor stocks, are fixed for all time, and local policies can have no possible effect on them. At the other extreme, when factors are infinitely substitutable, any mobile resources can can adjust completely independently of any other. This corresponds, in Figures 6 and 7, to the case of a perfectly elastic demand curve, i.e., to the case where $f_{i}\left(l_{i}\right)^{\prime}$ is fixed by technology, irrespective of the value of $l_{i}$. In this case, taxes or subsidies on any one factor of production will have no impact on the demand for or employment of any other factor of production. In intermediate cases, such as the Cobb-Douglas case where $\sigma=1$, stocks of productive resources adjust simultaneously, but not in fixed proportions, and the speed with which each adjusts depends on both its own adjustment costs and on the costs of adjusting other inputs. 


\subsection{Redistributive Transfers Financed by Taxes on Mobile Labor and Cap- ital}

Although this basic modeling framework is open to multiple applications, let us consider here what it may imply about the competition for highly-skilled labor. In this simple model, different factors of production are distinguished only by their degree of mobility, and the shares of income that they receive. Suppose, then, that there are three broad aggregates of inputs: the highly-skilled, capital, and a third aggregate interpreted to include low-skilled workers and any other productive inputs. Suppose that capital and highly-skilled labor are potentially mobile, while low-skilled labor and other productive inputs, such as land, minerals, or other natural resources, are completely immobile. ${ }^{8}$ Suppose also that the government in this jurisdiction uses tax and expenditure policies that redistribute income from highly-skilled labor and from capital toward low-skilled labor. What are the allocative and distributional consequences of changes in these policies? Specifically, when the magnitude of redistributive taxes and transfers go up or down, what are the effects on investment flows and on the migration of the highly skilled? How do these effects depend upon the "degree of mobility" of these resources? What are the effects of such redistributive transfers on the distribution of income in the local economy, and how do these effects change over time?

To explore these questions, assume that the local economy is initially in a long-run or stationary equilibrium. In order to quantify the impacts of changes in government policies, it is necessary to specify crucial parameters of the model, including the local elasticity of substitution in production, the parameters that govern the adjustment costs for skilled labor and capital, the shares of income that accrue to each of the three factors of production. As a benchmark case, let us suppose that unskilled and skilled labor each initially receive $40 \%$ of aggregate gross income, with capital receiving the remaining $20 \%$, and that the elasticity of substitution among all inputs is 1, as is the case if the production technology locally (i.e., in the neighborhood of the initial long-run equilibrium) corresponds to the Cobb-Douglas case. The assumption that the skilled labor share of aggregate income, or of half of all earnings, means that "skilled labor" corresponds approximately to the workers who, in the US economy, would constitute approximately the top 15-20\% of earners, depending on the year of observation (see Piketty and Saez (2003)), with the remaining half of earnings accruing to the lower $80-85 \%$ of earners, designated here as "unskilled". If applied to economies with a lower degree of earnings inequality in the US, the "skilled", in the following calculations, would correspond to a somewhat larger fraction of total earners.

The adjustment cost parameters are not of intrinsic interest in themselves, but can be selected so that the speeds of adjustment of skilled labor and capital - measured, in the

\footnotetext{
${ }^{8}$ Obviously, other interesting specifications are possible, and some are investigated in other research - see Wildasin (2011b).
} 
model, by the half-life of the adjustment process - correspond to empirically relevant values. To begin with, let us suppose that these parameters are such that the stock of skilled labor completes half of its adjustment, in response to a perturbation, in 5 years, and that the half-life of capital stock adjustment is only 2 years. The sensitivity of the results to variations in these parameters is of interest and is discussed further below.

In order to insure that policy changes are feasible, the government is assumed to be able to borrow or save at a fixed interest rate, and that it must balance its budget in present value terms. The interest rate $r$, which is also the interest rate at which households and firms are assumed to be able to borrow and save, is fixed at $3 \%$. Let $\tau_{1}$ denote the net fiscal burden on skilled labor, let $\tau_{2}$ denote the net fiscal burden on capital, and let the stocks of skilled labor and capital at time $t$ be denoted by the vector $k_{t} \equiv\left(k_{1 t}, k_{2 t}\right)$. These net fiscal burdens, like the variable $t_{i}$ appears in (3), represent the flow of all taxes paid by these factor owners, net of any cash or in-kind transfers, and net of the value of any monetized benefits from public goods or services that they may receive. ${ }^{9}$ The government budget constraint, in present-value terms, then requires that the total amount of net transfers to unskilled workers, $T$, must satisfy the condition

$$
\int_{0}^{\infty} T e^{-r t} d t=\int_{0}^{\infty}\left(\tau_{1} k_{1 t}+\tau_{2} k_{2 t}\right) e^{-r t} d t
$$

Without loss of generality, the initial values of skilled labor and capital are each set equal to one, as is the initial value of aggregate output and the aggregate amount of gross income. As initial values, let us assume that $\tau_{1}=.1$ and that $\tau_{2}=.05$; given the assumed factor shares, these values correspond to tax rates of $25 \%$ on factor incomes. Note that these should be understood as average effective tax rates, not marginal rates. Furthermore, they should be interpreted as net of the value of benefits received by taxpayers, and, in addition, they should be viewed as effective average "lifetime" net fiscal burdens. Obviously, without a much richer model that can accommodate life-cycle earnings growth, retirement, wealth accumulation, family formation and dissolution, and intergenerational linkages, including inter vivos transfers in cash and in kind, the treatment of tax and transfer policies is inevitably quite simplistic.

Using results developed elsewhere, ${ }^{10}$ and using the parameter values specified above, one can calculate the dynamic impacts of policy perturbations on the equilibrium stocks of skilled labor and capital. From this, it is then possible to determine the dynamic effects of policy perturbations on both gross and net returns to all factors of production. Suppose, for instance, that the government raises the tax burden on skilled labor, starting from the initial stationary state. A one-unit increase in this burden triggers a dynamic adjustment

\footnotetext{
${ }^{9}$ This abstracts from the possibility of differential valuations of public goods and services by different factor owners. The model also does not explicitly allow for benefits from purely public or non-congestable public goods and services, focusing instead on the empirically more relevant case where government expenditures finance programs for which benefits must be divided among beneficiaries.

${ }^{10}$ Specifically, see equations (22) in Wildasin (2011a).
} 
in which both skilled labor and capital are diminished gradually over time, as shown in Figure 8 . The fact that both of these factors are affected by a change in the tax on skilled labor reflects the fact that both are used simultaneously in the production process, and the speeds of adjustment for each, as depicted by the rate at which each factor stock converges (asymptotically) to its new steady-state value are jointly determined and jointly depend on the adjustment cost parameters assumed for each. Note that, as expected, there is almost no instantaneous change in the stock of either skilled labor or of capital: the "short run" impact on factor stocks is negligible, as is the impact on total output and gross income in the local economy.

Impact of Increased Tax Skilled Labor on Stocks of Skilled Labor and Capital

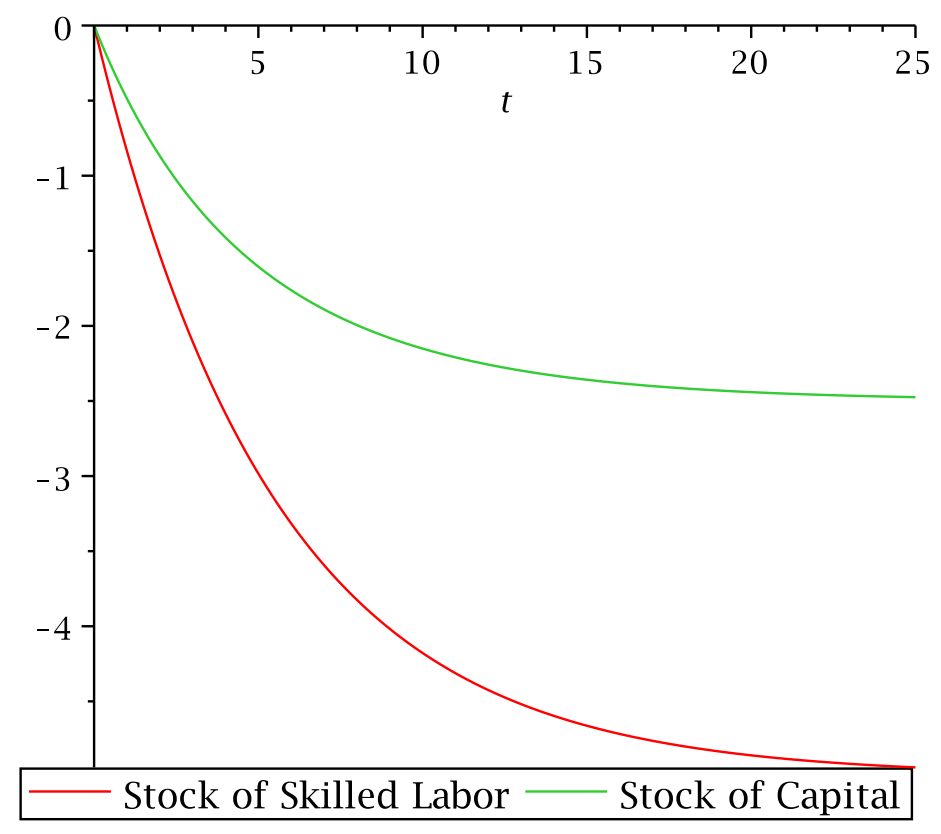

Figure 8 
With marginal productivity factor pricing, the changes in factor stocks shown in Figure 8 result in changes in the gross (i.e., before tax/transfer) returns to each factor of production. As shown in Figure 9, a higher net fiscal burden on skilled labor is offset by rising gross earnings for skilled workers: as the stock of skilled labor diminishes, its marginal productivity rises. Indeed, because the local economy is small and because skilled workers can obtain a fixed net return in external markets, the stock of skilled labor continues to fall until (asymptotically) the gross-of-tax return rises by 1 unit, that is, sufficiently to fully offset the higher tax. This corresponds to the case in the static model, illustrated in Figure 7 , in which the taxed factor is freely mobile, so that its stock falls sufficiently to raise its gross return by the full amount of the local tax. However, this effect materializes only asymptotically in the dynamic model with gradual factor stock adjustments. Note from Figure 9 that in the short run, the gross return to skilled labor is almost unchanged after an increase in $\tau_{1}$, corresponding to the case in the static model in which the taxed factor of production is completely immobile, so that its stock, and its gross return, is unaffected by local taxes and its net return falls by the amount of the local tax.

The dynamic path of adjustment of the gross return to the taxed factor of production thus, in a sense, encompasses both of the polar cases presented in the static model. At the same time, it reveals the limits of that analysis. Strictly speaking, the gross return to skilled labor is unaffected by increased taxes for only an instant; for all time periods $t>0$, the stock of skilled labor is smaller as a result of the increased tax, and its gross return is higher. Furthermore, the increase in the gross return to skilled labor only fully offsets the increased tax as $t \rightarrow \infty$; for all finite $t$, the gross return to skilled labor does not rise sufficiently to maintain the net return at its initial equilibrium level. In this sense, the static model fails to describe the impact of a change in policy for all finite times greater than 0, i.e., almost never.

As Figure 9 also shows, the impact of a change in the fiscal treatment of skilled labor has no long-run effect on the gross return to capital. Since the tax on capital is unchanged, its net return return can only be maintained at its long-run equilibrium value if the gross return is also unchanged. In the intermediate term, however, its gross return rises slightly, the result of offsetting effects as the ratio of capital to unskilled labor falls, while, in this case, the ratio of capital to skilled labor rises.

Finally, it is important to note that the gross return to unskilled workers gradually falls, as the stocks of the two mobile resources gradually decline in response to higher taxation of skilled labor. By the government's budget-balance constraint, unskilled workers benefit from increased transfers to them, at least so long as the effect of the increased tax on skilled workers is to increase total government revenues - which need not always be the case, but is true in the present instance. Figure 9 does not show, however, whether the increase in benefits from public-sector transfers is sufficiently great to offset the reduced gross income accruing to unskilled workers. Indeed, it is not exactly clear how to assess 
the impact of this tax/transfer policy on unskilled workers, since - as is also true for capital owners and for skilled labor - the policy changes the entire time path of factor returns. Since the gross return to unskilled labor is initially unaffected by the policy change, it is clear that higher taxes on the skilled must initially increase the net incomes (i.e., gross earnings plus net fiscal transfers) of the unskilled, but this initial net gain could conceivably be outweighed by subsequent declines in gross earnings.

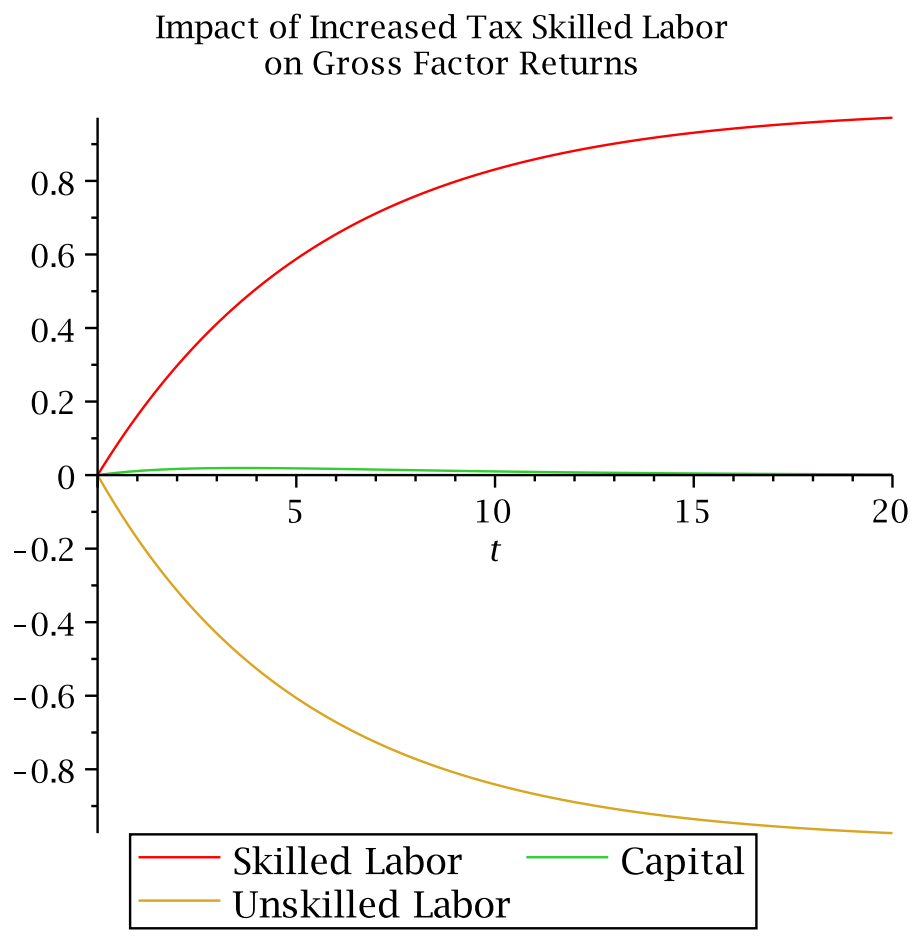

Figure 9

In order to evaluate the economic incidence of changes in redistributive policies in an intertemporal setting, perhaps the most natural approach is to calculate the present value of the changes in net incomes that they bring about. To put such present-value 
changes into proper context, it is helpful to express the magnitude of the policy changes themselves in natural economic units. This can be done by normalizing the size of the policy change so that it raises 1 unit more of tax revenue, in present value terms, or, equivalently, so that it finances a 1 unit increase in the size of transfers to unskilled workers, again expressed in present value terms. Under the parameter values assumed so far, then, a one-unit expansion of redistributive transfers turns out to raise the present value of gross wages for skilled workers by 1.85, and to raise the present value of gross returns to capital by .01. The present value of gross wages of unskilled workers fall by 1.86. The present value of net wages for skilled workers - that is, the increase in gross wages minus the present value of the higher taxes paid by these workers - is -0.31 . In other words, skilled workers experience a loss in net incomes, in present value terms, as a result of the imposition of higher taxes. The present-value change in net income for capital owners is just equal to the change in gross income, since their fiscal treatment does not change under this policy intervention. Unskilled workers of course are the recipients of redistributive transfers. However, perhaps surprisingly, unskilled workers are actually made worse off, on net, as a result of the expansion of redistributive transfers, even though they definitely gain from this program in the short run. In present value terms, the losses of gross earnings that they suffer turn out to be larger than the present value of the transfers that they receive, netting out to -0.86 . Under the above parameter values, the change in aggregate net incomes for all factor owners, in present value terms, is equal to -1.16 - a substantial loss, equal to more than $100 \%$ of the magnitude of additional transfers paid out to the unskilled.

These results are sensitive to the parameter values of the model. For example, unskilled workers definitely do benefit, in present value terms, if the tax rates on mobile factors are smaller - corresponding, say, to an initial tax on skilled workers of $\tau_{1}=.025$, or a tax of about $6.25 \%$ of earnings, and an initial tax on capital of 0 . Starting from the initial equilibrium under these tax rates, a one-unit increase in the present value of redistributive transfers raises the net income of unskilled workers, in present-value terms, by 0.036 , that is, by about $3.6 \%$ of the magnitude of the amount of transfers. This comes at a cost to skilled workers of about 0.16 , or about $16 \%$ of the magnitude of the transfers undertaken. Thus, even when the size of existing redistributive taxes and transfers are rather modest, the "excess burden" of incremental increases local redistributive policies, i.e., the aggregate net losses that arise because of dynamic factor responses to changes in policy are quite substantial. These are the dynamic equivalents, essentially, to the area bcd in the static analysis displayed in Figure 7.

How would these results differ if mobile factors were "less mobile"? One way to address this question is to examine similar policy experiments while varying the adjustment cost parameters in the model so that skilled labor and capital respond less quickly to policy changes. When this is done so that adjustment speeds are about half as fast, the qualitative results remain fairly similar to those just described, but the results differ 
substantially in quantitative terms. In particular, unskilled workers are still harmed by redistributive transfers if the initial tax burdens on skilled labor and capital are relatively high $\left(\tau_{1}=.1\right.$ and $\left.\tau_{2}=.05\right)$. With slower adjustment speeds, the net present-value loss to skilled workers from a one-unit expansion in redistributive transfers is larger, at -0.49 (compared to -0.31), while the net loss to unskilled workers is reduced from -0.86 to -0.34, with an aggregate net loss of -0.84. In other words, the taxpayers (the skilled) are harmed more by higher taxes when they are less mobile. The recipients of redistributive transfers are still harmed, but not as much. When redistributive policies are initially smaller $\left(\tau_{1}=.025\right.$ and $\left.\tau_{2}=0\right)$, the harm to skilled workers from an incremental increase in redistributive transfers only amounts to $29 \%$ of the increase, while unskilled workers, the recipients of these transfers, experience a net gain equal to $19.7 \%$ of the transfers. The net loss of income to all factor owners is now just $10 \%$ of the increase in transfers.

As a third and final case, if the mobility of skilled labor and capital is reduced still further, so that the half-life of the response to a change in policy rises to about two decades, the results change again, and in the same direction. Now, unskilled workers benefit, on net, from an incremental increase in redistributive transfers, even when the initially given fiscal burdens on skilled labor and capital are relatively high $\left(\tau_{1}=.1\right.$ and $\left.\tau_{2}=.05\right)$ : per unit increase in program size, unskilled workers enjoy a net gain in real income of 0.19 , while skilled workers suffer a loss in real income of 0.72 . The reduction in aggregate net income falls to just 0.50 . If the initial size of the redistributive program is twice as large, however, corresponding to values of $\tau_{1}=.2$ and $\tau_{2}=.1$, the distortionary effects of the program rise once again and the present-value net income change for unskilled workers, once again, becomes negative.

\subsection{Policy and Political Economy Implications}

Although the preceding calculations are based on a highly stylized model, they at least serve to illustrate some of the policy tradeoffs involved in the formulation of tax and transfer policies when households at the upper end of the earnings distribution - the highly skilled - are potentially mobile. Most fundamentally, the analysis shows how important it is to take into account the fact that although stocks of productive resources do adjust to changes in real incomes via migration and investment flows, they do so only gradually. One must therefore distinguish between the "short-run", "long-run", and "intermediate-run" impacts of such policies. The comparative statics analysis outlined in Section 3.2 provides key insights into the short- and long-run effects of policy changes, but it cannot capture the "intermediate" impacts - those that begin immediately after a policy change is initiated, and that only die away asymptotically.

In the early stages of an expansion of redistributive transfers, those who are taxed more heavily - the highly skilled - are sure to suffer a loss in net income, and those who receive 
larger transfers - the unskilled - are sure to be better off. In the late stages, reductions in the stock of skilled labor and capital raise the gross returns to these factors, while depressing the gross return to unskilled labor. This means, of course, that the underlying distribution of gross income becomes more unequal as a result of the policy change, and that the distribution of net income, even if more equal, does not shrink by the full magnitude of the redistributive transfers themselves.

To assess the full impact of the policy over its entire time horizon, it is necessary to add up changes in real incomes at different points in time. Calculating the net present value impacts of incremental changes in redistributive policy shows that the harm inflicted on highly skilled workers and the gains enjoyed by unskilled workers are sensitive both to the speed of dynamic factor adjustment and to the initial scale of existing policies. With relatively rapid factor adjustment responses, in fact, unskilled workers actually suffer losses in the present value of net incomes, as losses in gross earnings are less than fully offset by higher transfer payments. These losses are particularly severe in the case of incremental expansions of policies that are initially already highly redistributive. Such relatively rapid responses are to be expected when regions are highly integrated with external markets, as is the case, for example, for US states. Slower adjustment speeds are more likely, on the other hand, at the international level. When skilled labor and capital respond only very slowly to policy changes, such as might have been the case in, say, the middle decades of the previous century, the distributional impacts of changes in policy are significantly affected. When those who finance redistributive transfers are relatively immobile, gross factor prices do not change rapidly in an unequalizing direction, so that the net income distribution is narrowed to a greater extent, and for a longer period of time, as compared with the case of high mobility.

Although it is not possible here to discuss in any detail the political economy implications of factor mobility, it should be obvious that the demand for redistributive transfers, and the resistance to heavier fiscal burdens on the part of those with higher incomes, may be quite sensitive to the degree of factor mobility. Explicitly dynamic analysis highlights the differing intertemporal impacts of redistributive transfers and this raises important questions about the extent to which current policies are shaped by agents who may possibly act myopically, especially if those whose future interests are affected by policy are not well represented in the policymaking process. ${ }^{11}$

\footnotetext{
${ }^{11}$ The importance of such dynamic considerations for the analysis of political economy is discussed further in Wildasin (2006).
} 


\section{Conclusion}

There are many determinants of human capital mobility. These include intrinsic "technological" determinants of mobility, such as direct out-of-pocket costs associated with relocation, which are affected, notably, by changes in transportation technologies, but also by costs related to housing markets (selling costs of houses, for instance). "Information" costs arise because people do not have perfect knowledge about economic and other opportunities in other locations. "Social" costs, such as the cost of adapting to new languages, customs, ethnic environments, and other aspects of living arrangements also affect the ease with which people may move from place to place. Many of these determinants are not readily within the direct control of policymakers. There are, however, many determinants of human capital mobility that are directly or indirectly influenced by public policies. Let us briefly recall what some of these are, and then review some of the implications of such policies, especially in light of the preceding analysis.

First and foremost, mobility is affected by direct legal controls over migration. These are most obvious, and perhaps most frequently discussed, in the context of international migration. Within the past several decades, the world has witnessed several dramatic changes in these aspects of migration control: the evolution of ever more relaxed border controls with the countries of the European Union, including not only changes in the formalities that govern employment and residence by citizens of EU nations who relocate to other EU member states, but perhaps even more importantly the accession of new member states themselves, through progressive expansion of the EEC/EU from the original six founding nations in 1959, to nine countries by 1973 (about a one-third increase in total population), to a dozen countries by 1986 (another 20\% population increase), to fifteen countries by 1995 (approximately another 10\%), to 25 countries by 2004 and 27 countries at present (approximately another $25 \%$ population expansion). EU membership by itself results in a major change in the degree of mobility for residents of new member states. Other equally dramatic events - intertwined, to some degree, with the EU expansion just described - include the collapse of the Soviet Union, which, accompanied by the end of the Warsaw Pact and German reunification, drastically eased migration constraints for the populations of Eastern Europe. In other parts of the world, direct controls over migration and employments are exercised within countries. This was true of the former Soviet Union, of South Africa during the apartheid era, and of China, formerly and, to a lessened degree, still today via the hukou system (see, e.g., Wildasin (2003b) for more discussion).

A host of other government policies indirectly affect the degree of human capital mobility. The tax treatment of relocation costs, regulatory barriers to employment or acquisition of housing, the degree of enforcement of border controls and other regulations, the presence and extent of linguistic, cultural, and other accommodations offered to immigrants, and 
access to public services and participation in social welfare systems available to immigrants are all influenced by policy decisions. Policies that facilitate language acquisition, cultural adaptation, and the building of spatial networks can certainly help to reduce barriers to migration.

Human capital investment is closely linked to household mobility. Empirically, the linkage between mobility and education is well-established. Better-educated people often possess, or are well able to acquire, specialized skills that make them attractive to potential employers seeking to expand employment in new and growing sectors of the economy. These employment opportunities may well arise in places different from, and possibly quite distant from, a person's place of birth. The range of such opportunities that a person may confront over a working lifetime that may span four or more decades is difficult to foresee, but it is clear that a worker's opportunity set expands as the degree of mobility increases. Thus, the return to investment in human capital is enhanced for those whose "opportunity sets" for future employment are large. Those who seek and acquire high levels of human capital have especially high incentives to improve their capacity to work productively on a multi-regional, multinational, and, ultimately, on a global basis. The mobility of all people, but especially the mobility of the highly educated, can be enhanced through their education in their home regions and countries, through exposure to other languages, institutions, and cultures via electronic media, and, of course, through participation in educational exchanges, temporary employment, and even tourism. Many public policies - notably, in the education sector itself - can facilitate or impede such mobility-enhancing activities.

Policies that increase human capital mobility can certainly contribute to more productive utilization of human resources. Concrete evidence of such productivity is provided by analyses that show how those who migrate enjoy higher earnings. The beneficiaries of higher earnings, of course, include migrants themselves. But the spatial reallocation of human capital has much more far-reaching consequences, as well. The movement of people - and the associated expansion or contraction of capital stocks, output, and other elements of economic activity, affect both origin and destination regions. These effects need not occur instantaneously, and, indeed, their cumulative effects may dwarf, and even reverse, their short-run impacts. Section 4 has outlined a framework for the analysis of the dynamic impacts of fiscal policies, which can influence the incentives for people, and other productive resources, to locate in a particular jurisdiction. While stylized, that analysis shows that redistributive tax/transfer policies, such as taxes that are imposed on higher-income households and that are used to transfer cash or (more broadly) inkind benefits to lower-income households, can harm the former and help the latter in the short-run (the presumed goal of such policies), but that the harm to the former can diminish over time as highly-skilled workers have opportunities to escape the fiscal burden of redistribution, while the benefits to the latter likewise diminish over time. 
An assessment of the lifetime or present-value impact of redistributive policies must weigh the short- and long-term consequences together. If resources - such as highlyskilled workers - are comparatively immobile, long-run effects only gradually arise and their weight, in present-value terms, is small. When resources are highly mobile, however, long-run impacts emerge more rapidly and short-run effects die away quickly. Although the preceding analysis does not specifically attempt to model the political economy of redistributive policy, it certainly points in the direction of suggesting that increased resource mobility can significantly alter the benefits and costs of redistributive policies, as seen both by those who are the putative beneficiaries of such policies and by those whose net incomes and economic well-being the policies are designed to diminish.

There is then the prospect of important policy interactions. Policies that enhance the mobility of highly-skilled workers may shift the political and normative benefit/cost calculus toward tighter limits on redistributive policies. The effective capture of resources from higher-income households may become more difficult, and less prevalent, as education and other policies contribute to greater mobility, especially for the highly skilled. Within a highly-integrated economic region such as the US, it may be relatively difficult for subnational governments to sustain high levels of redistributive activity. Perhaps this can help to explain, within the US context, why the Federal government plays the predominant role in redistributive policies in the US, relegating states and localities to relatively minor roles, except perhaps insofar as their contributions to redistribution are supported by Federal programs via intergovernmental transfers.

Human capital mobility seems destined to rise over time throughout the world, driven in part by fundamental demographic shifts, by improving technologies that lower the costs of mobility, and by expansions of human capital investment. At least, such appears to have been the case during the past half-century and, indeed, over much longer periods. Increased mobility may ultimately not only add constraints that limit the redistributive capacity of existing jurisdictions, but may also create incentives for expansion of redistributive activities by higher-level governments that may then supplant the activities of governments that presently play a relatively prominent role in redistributive policy. Such, at least, would be one interpretation of US experience during the past century. Whether such institutional and policy evolution will occur elsewhere remains to be seen. 


\section{References}

Andersson, F. and K. Konrad (2001), "Globalization and Human Capital Formation" IZA DP no. 245.

Andersson, F. and K. Konrad (2003), "Human capital investment and globalization in extortionary states", Journal of Public Economics, 87/7-8,1539-1555.

Barrett, A., J. Fitzgerald, and B. Nolan (2000), "Earnings Inequality, Returns to Education and Immigration into Ireland", IZA Discussion Paper No. 167.

Barrett, A. (2002), "Return Migration of Highly-Skilled Irish into Ireland and Their Impact on GNP and Earnings Inequality", in OECD (2002), 151-157.

Bhagwati, J. N. (1976a), The Brain Drain and Taxation, Vol. 2: Theory and Empirical Analysis (North-Holland, Amsterdam).

Bhagwati, J. N. (1976b). Taxing the Brain Drain, Vol. 1: A Proposal ( North- Holland, Amsterdam).

Bollinger, C. and P. Hagstrom (2008), "Food Stamp Program Participation of Refugees and Immigrants? Southern Economic Journal 74, 665-692.

Bös, D. and S. Cnossen, editors, Fiscal Implications of an Aging Population (Berlin: Springer, 1992).

Collado, M. D. and I. Iturbe-Ormaetxe (2004), "Quantifying the Impact of Immigration on the Spanish Welfare State," International Tax and Public Finance 11, 335-353.

Coulson, B. G. and D. J. Devoretz (1993), "Human Capital Content of Canadian Immigrants: 1967-1987", Canadian Public Policy 29, 357-366.

de la Croix, D, and P. Monfort (2000) "Education Funding and Regional Convergence" Journal of Population Economics, 13, 403-424.

Dang, T. T., P. Antolin and H. Oxley (2001), "Fiscal Implications of Ageing: Projections of Age-Related Spending?, OECD Economics Department Working Papers, No. 305, OECD Publishing. http://dx.doi.org/10.1787/503643006287

Docquier, F., O. Faye, and P. Pestieau (2008), "Is migration a good substitute for education subsidies?", Journal of Development Economics 86, 263-276.

Docquier, F. and H. Rapoport (forthcoming), "Globalization, brain drain and development", Journal of Economic Literature. 
Ehrenberg, R.G. and R.S. Smith (1988), Modern Labor Economics: Theory and Public Policy, 3rd. ed. (Glenview, Illinois: Scott Foresman).

European Commission (2005), "The 2005 EPC Projections of Age-Related Expenditure (2004-2050) for the EU-25 Member States: Underlying Assumptions and Projection Methodologies," European Economy Special Report No. 4/2005.

Gustman, A.L. and T.L. Steinmeier (2000), "Social Security Benefits of Immigrants and U.S. Born," in G. J. Borjas (ed.), Issues in the Economics of Immigration (Chicago: University of Chicago Press), 309-350.

Hamilton, B., and J. Whalley (1984), "Efficiency and Distributional Implications of Restrictions on Labour Mobility", Journal of Development Economics 14, 61-75.

Hansen, J. and M. Lofstrom (2009), Journal of Population Economics, 22(4), 941-970.

Hansen, J. and M. Lofstrom (2003), "Immigrant Assimilation and Welfare Participation: Do Immigrants Assimilate Into or Out-of Welfare?" Journal of Human Resources 38, 74-98.

Hatton, T. J., and J. G. Williamson (1998), The age of mass migration ( Oxford: Oxford University Press).

Ihrke, D.K., C.S. Faber, and W.K. Koerber (2011), "Geographical Mobility: 2008-2009", Current Population Reports, P20-565. U.S. Census Bureau, Washington, DC.

Katz, E. and H. Rapoport (2005), "On Human Capital Formation with Exit Options", Journal of Population Economics 18 267-274.

Kennan, J. (2011), "Higher Education Subsidies and Human Capital Mobility", unpublished.

Kodrzycki, Y. K. (2001), "Migration of Recent College Graduates: Evidence from the National Longitudinal Survey of Youth", New England Economic Review.

Lien,D. Y. Wang (2005), "Brain Drain or Brain Gain: A Revisit", Journal of Population Economics, 18, 153-163.

Lindert, P.H. and J.G. Williamson (2003), "Does Globalization Make the World More Unequal?", in Michael D. Bordo, Alan M. Taylor and Jeffrey G. Williamson (eds.), Globalization in Historical Perspective (Chicago: University of Chicago Press), 227-271.

Marchiori, L., I.-L. Shen, and F. Docquier (forthcoming), "Brain drain in globalization A general equilibrium analysis from the sending countries' perspective", Economic Inquiry. 
O’Rourke, K.H., A.M. Taylor, and J. G. Williamson. 1996. "Factor price convergence in the late nineteenth century," International Economic Review 3\%, 499 ?530.

O'Rourke, K. H., and J. G. Williamson(1999), Globalization and history (Cambridge: MIT Press).

Partridge, M.D., D.S. Rickman, M.R. Olfert, and K. Ali (2012) "Dwindling U.S. Internal Migration: Evidence of a Spatial Equilibrium or Structural Shifts in Local Labor Markets?? Regional Science and Urban Economics 42, 375-388.

Piketty, T. and E. Saez (2003), "Income Inequality in the United States, 1913-1998", Quarterly Journal of Economics, 118, No. 1 (Feb., 2003), 1-39.

Ren, P. (2011), "Lifetime Mobility in the United States: 2010", American Community Survey Briefs, U.S. Census Bureau, Washington, DC.

Riphahn, R. T. (2004), "Immigrant Participation in Social Assistance Programs: Evidence from German Guestworkers," Applied Economics Quarterly, 50 (4), 329?362.

Storesletten, K. (2000), "Sustaining Fiscal Policy Through Immigration," Journal of Political Economy 108, 300-323.

Thum, C. and S. Uebelmesser (2003), "Mobility and the role of education as a commitment device", International Tax and Public Finance 10, 549-564.

Vasileva, K. (2012), Population and Social Conditions 31/2012, Eurostat.

Vidal, J.P. (1998), "The Effect of Emigration on Human Capital Formation", Journal of Population Economics 11, 589-600.

Wadensjö, E. and H. Orrje (2002), Immigration and the Public Sector in Denmark (Aarhus: Aarhus University Press).

Walmsley, T.L., A. Winters, and A. Ahmed (2011), "The Impact of the Movement of Labour: Results from a Model of Bilateral Migration", Global Economy Journal 11.

Wildasin, D.E.,(1995), "Factor Mobility, Risk, and Redistribution in the Welfare State," Scandinavian Journal of Economics 97, 527-546.

Wildasin, D.E. (1998), "Factor Mobility and Redistributive Policy: Local and International Perspectives," in P. B. Sorensen (ed.) Public Finance in a Changing World (London: MacMillan Press, Ltd.), 151-192.

Wildasin, D.E. (1999), "Public Pensions in the EU: Migration Incentives and Impacts," in A. Panagariya, P.R. Portney and R.M. Schwab (eds.), Environmental and Public Eco- 
nomics: Essays in Honor of Wallace E. Oates (Cheltenham: Edward Elgar), 253-282.

Wildasin, D. E. (2000), "Labor Market Integration, Investment in Risky Human Capital, and Fiscal Competition," American Economic Review 90, 73-95.

Wildasin, D. E. (2003a), "Fiscal Competition in Space and Time," Journal of Public Economics 87, 2571-2588.

Wildasin, D. E. (2003b), "Liberalization and the Spatial Allocation of Population in Developing and Transition Countires", in J. Martinez-Vasquez and J. Alm (eds.), Public Finance in Developing and Transition Countries: Essays in Honor of Richard Bird (Cheltenham: Edward Elgar Publishing), 63-100.

Wildasin, D. E. (2005), "Fiscal Policy, Human Capital, and Canada-US Labor Market Integration," in Richard G. Harris and Thomas Lemieux (eds.), Social and Labour Market Aspects of North American Linkages (Calgary: University of Calgary Press), 489-536.

Wildasin, D.E. (2006), "Fiscal Competition", in B. Weingast and D. Wittman (eds.), Oxford Handbook of Political Economy (Oxford: Oxford University Press).

Wildasin, D.E. (2009), "Public Pensions and Demographic Change in Developed Countries: Fertility Bust and Migration Boom?", in J. Bhagwati and G. Hanson (eds.), Skilled Immigration Today: Problems, Prospects, Policies (Oxford: Oxford University Press, 2009), 81-129.

Wildasin, D.E. (2011a), "Fiscal Competition for Imperfectly-Mobile Labor and Capital: A Comparative Dynamic Analysis", Journal of Public Economics 95, 1312-1321.

Wildasin, D.E. (2011b), "Fiscal Competition, Redistributive Transfers, and Factor Mobility in a Dynamic Context", unpublished.

Wilson, J.D. and D.E. Wildasin (2004), "Capital Tax Competition: Bane or Boon?" Journal of Public Economics 88 1065-1091. 